\title{
Sharing Information on COVID-19: the ethical challenges in the Malaysian setting
}

\section{Aimi Nadia Mohd Yusof ${ }^{1}$ (D) Muhamad Zaid Muuti $^{1} \cdot$ Lydia Aiseah Ariffin $^{1} \cdot$ Mark Kiak Min Tan ${ }^{1}$}

Received: 28 April 2020 /Revised: 1 June 2020 / Accepted: 2 June 2020 /

Published online: 25 June 2020

(C) National University of Singapore and Springer Nature Singapore Pte Ltd. 2020

\begin{abstract}
The COVID-19 pandemic has raised challenges in dealing with information sharing by the public and the authorities. There are two categories of information sharing on social media that are believed to be potentially problematic and unethical: the sharing of personal information of patients and the sharing of fake news or false information. We present a discussion on how the response to the COVID-19 pandemic in Malaysia can be ethically handled in terms of information sharing. It is recommended that the public should cultivate the basic skills to evaluate information and determine its validity. On the other hand, the authorities should refrain from placing the blame on patients to avoid them from being stigmatized. It is crucial that all parties are aware of their ethical duty to ensure only ethical and valid information gets shared on social media.
\end{abstract}

Keywords COVID-19 · Pandemic · Public interest · Information sharing · Confidentiality · Privacy

\section{Introduction}

The current coronavirus disease 2019 (COVID-19) pandemic caused by the severe acute respiratory syndrome coronavirus 2 (SARS-CoV-2) has resulted in an international public health emergency and created unprecedented ethical challenges towards the response in handling the situation. The short history of COVID-19 began in December 2019 with reports of patients with pneumonia of unknown aetiology being

Aimi Nadia Mohd Yusof

aiminadia@uitm.edu.my

1 Medical Ethics and Law Unit, Faculty of Medicine, Universiti Teknologi MARA, Selangor, Malaysia 
diagnosed in China, which quickly turned into an outbreak (BBC News 2020). While Chinese officials declared a lockdown of Wuhan on 23 January 2020, this failed to deter the spread of the virus around the world. The World Health Organization (WHO) declared the COVID-19 outbreak to be a Public Health Emergency of International Concern (PHEIC) on 30 January 2020, and subsequently a pandemic on 11 March 2020 (WHO 2020a).

Cases have increased exponentially since the initial detection of this disease involving more than 185 countries and territories worldwide (WHO 2020a). More than 1.6 million cases were confirmed with over 100,000 deaths by mid-April 2020 and this tally surpassed 5 million cases cumulatively with over 300,000 deaths by mid-May 2020 (WHO 2020a). Lockdowns and various other public health measures that encourage social distancing have been implemented in many countries in the attempt to 'flatten the curve'. Malaysia and its neighbouring countries have also not been spared this ordeal.

It is never easy facing the unknown, and amid the fear in the midst of this pandemic with a novel virus, there have been a host of different reactions. For governments, there has been a need to balance between containing the problem in the name of public health and the performance of the economy. There is also a need to ensure that excessive anxiety and subsequent panic are not induced by the irresponsible spread of fake news. On a societal level, this can cause a loss of confidence in the government's decisions and policies on how it handles the pandemic, economic recessions, retrenchments and unemployment (Greenberg and Rosner 2020). On an individual level, this may cause panic buying and hoarding (Lai 2020), psychological distress (Ministry of Health Malaysia 2020a) and instil fear among certain groups within the population.

In Malaysia and many other affected countries, we believe that there are two problematic categories of information sharing on social media that worsen the situation. Firstly, the sharing of personal information of patients and their families by the public, the authorities or third parties, and secondly, the sharing of fake news or false information. The sharing of personal information raises the risk of stigmatization, discrimination and blame. There is an increased risk that the public may start blaming patients with COVID-19 openly for initiating clusters of infection, and indeed, in some cases, these patients have had to respond openly to such allegations to defend themselves (Atan 2020; Sukumaran 2020). The sharing of false information is not unique particularly for this pandemic, but the impact is causing the public to be anxious and fearful (Ortutay and Klepper 2020; de la Garza 2020).

In this paper, we discuss how the response to the COVID-19 pandemic in Malaysia with regard to information sharing can be ethically handled. This includes understanding the difference between information that is disclosed in the interest of the public and information that is interesting to the public. This understanding is essential in determining information that is ethical to be published publicly for reading and sharing. We will examine the two problematic categories of information sharing and how the public and the authorities should react responsibly in handling them. We will also provide some recommendations on how the public can determine information validity during this pandemic. 


\section{The problems}

\section{The sharing of personal information of patients}

Since the beginning of the COVID-19 pandemic, Malaysians have witnessed a series of patients' personal information being leaked into social media. For instance, a patient known as 'Patient 16' had become a target of hate and discrimination after his name and profile picture were widely circulated on social media, which continued even after he was cleared of the virus (The Star 2020b). In other cases, the sharing of personal information regarding 'Patient 26' and 'Patient 136', who were alleged to be 'superspreaders', have necessitated them to defend themselves publicly on social media (Atan 2020; Sukumaran 2020). Unfortunately, their actions resulted in further criticisms being made towards them. These three examples illustrate that the protection of patients' privacy in a pandemic is a critical step in deterring stigmatization, discrimination and blame.

\section{The sharing of fake news or false information}

Information related to this new pandemic transmits very rapidly online. While the virtually instantaneous dissemination of information may be helpful in some circumstances, verifying the accuracy of the disseminated information can be potentially problematic causing an 'infodemic' (Zarocostas 2020). The WHO defines an 'infodemic' as an excessive amount of information which consist of some inaccuracies that cause difficulties for the public to obtain reliable information and dependable advice when they require it (WHO 2020b). The problem with spreading unverified information occurs when irresponsible citizens share fake news or false information around. This has the potential to expose unsuspecting members of the public to being deceived that information is true. This is morally unacceptable, especially when the spread of such information is shared intentionally to deceive others.

Fake news is composed of intentionally misleading news that may not be entirely wrong with the aim to influence views (Kanekar and Thombre 2019). On the other hand, false information, which is a subcategory under the broad wings of fake news, consists of intentionally fabricated stories that are routinely generated to publicize certain agenda (Molina et al. 2019). Infodemic results in making efforts to contain the pandemic more complicated due to the effects of publicizing needless alarm and uncertainty, and dividing society. This is especially unhelpful when unanimity and collaboration are the basis to fight the outbreak, save lives and put an end to this pandemic (Hao and Basu 2020).

\section{Interesting to the public versus public interest}

When a pandemic such as COVID-19 emerges, it is important that the authorities take necessary measures to calm the public to avoid overwhelming responses that can create unnecessary disturbances to the situation. In such a context, it is important to determine whether the dissemination of information is merely interesting to the public or whether the disclosure of some information is in the public's best interest. The distinction 
between these provides guidance on how to ethically respond to information and decide when the spread of information is necessary and ethical. It is important to ensure that the spread of information is done in an ethical and socially responsible way as it will also help to maintain the public's trust. This paper will now focus on the concept of public interest to justify the act of sharing information by the public and the authorities.

\section{The concept of public interest}

Prior to embarking on discussing the problematic categories alluded to earlier, it is important to define what 'public interest' means. This can be defined as the "general welfare and rights of the public that are to be recognised, protected, and advanced" (British Medical Association 2020). A matter is of 'public interest' when it affects the general public or a group within the society (Keong et al. 2016), when it raises issues of public concern, or when there is "impact on disadvantaged or marginalised groups" (Martin 2003). Since this pandemic affects the general public across the globe, it needs to be considered as a matter of public interest.

Disclosure of information based on the consideration of public interest during this pandemic must be weighed against the principles that govern the basic rights of an individual such as the right to be respected for personal autonomy, privacy and confidentiality. The benefits of disclosing the information must outweigh the harms that may be imposed on those individuals affected with COVID-19 for the action to be justified as ethical. These benefits should reflect an overall good to the general public to overcome this pandemic especially those aimed at protecting the public's safety against the disease.

\section{Information the public considers interesting}

The SARS-CoV-2 virus has the potential to infect any individual member of the community. Hence, in their effort to understand the disease better and to avoid getting infected, the public will generally find most information, news or stories regarding the disease interesting. Since there are still many uncertainties surrounding the risks and nature of the disease, it is understandable that any information related to the disease would be appealing at this stage. Journalists, bloggers or anyone with access to social media may see the pandemic as an opportunity to obtain extra attention, increase readership rates or increase the number of their followers by publishing information related to COVID-19. In the process of doing so, valid information may be manipulated and fabricated leading to fake news or stories in order for it to appear more interesting to the public.

Additionally, irresponsible parties may capitalize on the public's panic as a profiteering opportunity. Examples of this include the marketing of fake COVID-19 home test kits and the promotion of 'miracle cures' which claim to cure or prevent COVID-19 (Knight 2020). In the midst of panic, members of the public may resort to any measures which in their opinion may protect them without verifying whether the information is accurate or otherwise. Left unchecked, information that reaches the public can cause public uproar and may cause unnecessary fear to the public.

Despite the previous examples, one of the main aims of disseminating information during a pandemic is to create awareness among the public, especially regarding new 
discoveries and updates on COVID-19 and emphasizing public health measures such as social distancing. Social media can be an effective platform to meet this aim. One of the ways in identifying whether information shared is interesting to the public but not in the public interest is when there is no beneficial impact to the public on knowing the given information.

\section{Information considered to be of public interest}

The revelation of information only becomes of 'public interest' when the information affects the public or is a matter of public health policy. Such information can be seen as beneficial when knowing the information helps to generate awareness among the public to protect themselves against the disease. It is reasonable to believe that a common good for the public would outweigh the private interests of an individual or a few individuals. A well-recognized shift from patient-centred duty of care to a more public-focused duties occur to ensure the safety of the general public. This may at times necessitate utilitarian-based decisions which may not be in the best interests of individual person (Berlinger et al. 2020). One such instance is the revealing of a COVID-19 patient's travel history or contact history (Department of Health 2020).

Despite the justification for the breach of confidentiality in view of public interest, there are risks attached to this action. Social stigmatization can occur if the breach is not properly done. Information on patients can be published widely on social media without scrutiny and may lead to the deterrence of possibly affected individuals to come forward for investigations in fear of socially being stigmatized. As such, where a breach of patient confidentiality is justified on the basis of public interest, the information will need to be properly examined to ensure only accurate and necessary details are being shared to the public.

\section{The role of a responsible public in dealing with information on COVID-19}

\section{Dealing with personal information of patients}

The public may think that sharing personal information about a patient infected with COVID-19 with others on social media is an appropriate action to show that they care about the community and to prevent further spread of the disease. However, they may not realize that some of the consequences of this action may result in having victimized the patient, breached the patient's personal space on social media and the patient's right to privacy (United Nations 1948). In fact, members of the public should, as much as possible, refrain from sharing information about affected patients especially when such information clearly expose personal details about them. It is best to leave the sharing of such information in the hands of the relevant authorities.

The public should understand that there is no clear justification to the need to know in detail about a patient's personal information unless the information is provided directly by the authorities to the person during the contact tracing process. Being a responsible member of the public means placing importance on respecting the privacy 
of affected individuals and following the advice and directives provided by the responsible health authorities to avoid the spread of infection.

\section{Dealing with fake news or false information}

In addition, every member of the public has the duty and responsibility to fight against fake news and inaccurate information (Kanekar and Thombre 2019; West 2017). To win this fight, every member of the public has the responsibility to carefully read, learn to respond and only disseminate accurate health-related information (West 2017).

On the receiving end, members of the public can protect themselves from fake news and inaccurate information by following only verified sources and organizations with diverse standpoints and verify the validity of information from legitimate resources. Receiving news and following updates from a small group of like-minded opinion and belief with a limited range of resources will increase the chance for that reader to be deceived by wrong and unvalidated information. In Malaysia, the public now has easy access in obtaining official updates from the relevant authorities via social media platforms such as those of the Ministry of Health $(\mathrm{MoH})$ Crisis Preparedness and Response Center (CPRC) and the National Security Council Facebook pages and Telegram channels.

In the digital world, every member of the public should have some reservations concerning the information received from multiple sources. Digital readers need to understand that not all information published online is factual (Wang et al. 2019). It is highly recommended that every digital consumer cultivates the skill to determine inaccurate information to protect oneself from fake news and also from being the source of spread of the breach of privacy of those affected. At the very least, the basic habit that all digital consumers can acquire is verifying every received information against trusted authorities such as the National Security Council, the $\mathrm{MoH}$ and the WHO. A better approach may be to acquire critical thinking skills and to enhance health and social media literacy. This method will provide every person with the ability to critically evaluate the trustworthiness and reliability of every health information.

In order to increase public health literacy during a pandemic, appointed public health and other responsible authorities will need to increase their efforts in disseminating user-friendly and easy-to-understand guidelines for targeted groups. In response to the pandemic, the Malaysian Government has shown great effort by developing and launching the MySejahtera application to assist in managing the COVID-19 pandemic in the country by providing basic guidelines and regular updates to the public. With the support of the government and health authorities, responsible members of the public will have a better understanding of their significant role in helping to enhance the country's effort in fighting against the progressive significant social phenomenon.

\section{The role of the authorities in responding to information on COVID-19}

\section{The sharing of personal information of patients}

The principle of confidentiality is the foundation of the relationship of trust between patients and healthcare professionals (HCPs). This relationship of trust is essential as it 
encourages patients to be transparent in disclosing their medical history. However, the principle of confidentiality is not absolute. In Malaysia, the Malaysian Medical Council (MMC) guidelines on Confidentiality (Wah et al. 2011) provide two conditions where confidentiality can be breached without the patient's consent. Firstly, the disclosure is permissible if it is mandated by law. For example, in the current pandemic, the Prevention and Control of Infectious Diseases Act 1988 can be invoked requiring HCPs to disclose personal information of patients such as their name, age, gender, ethnicity, nationality, residential and work address to the relevant health authorities. This information enables them to perform contact tracing and authorize an 'enhanced movement control order' or total lockdown in locations identified to have a high number of confirmed cases.

Another condition where the guidelines permit disclosure without consent is when the disclosure is done for the purpose of public interest. Since the beginning of the pandemic, the Director-General of Health has fulfilled this role by releasing daily press statements regarding the COVID-19 status in the nation. The public is informed daily of the number of newly confirmed cases, the number of cases being discharged, the number of cases in the intensive care units, and the number of mortality cases. The press statement is widely reported in the media and shared across multiple social media platforms. Additionally, the press statements would also disclose locations of newly detected clusters and would advise members of the public who have been exposed to come forward for testing.

The Malaysian government has been pressured at times to reveal the identity of all those infected by COVID-19 but it has commendably never yielded to such demands (Hamid and Rahim 2020). However, even when the patient's personal information is anonymised, we argue that the present information sharing may have inadvertently incited stigma against COVID-19 patients in Malaysia. In this section, we will discuss on the strategies to overcome this.

\section{Ending the blame in risk communication}

Effective risk communication will not only alleviate anxiety and panic among the community but also educate them to adopt necessary preventive measures. One example of an effective risk communication in Malaysia is the daily press statement by the Director-General of Health. The consistent updates by the Director-General of Health have allowed him to be recognized globally as a 'top professional' in the fight against COVID-19 (The Star 2020a).

However, the press statements on numerous occasions have arguably led to the stigma against those infected. For example, in the case of 'Patient 26', a diagram that clearly linked him to 21 other patients was published on 4 March 2020 (Abdullah 2020a). The diagram implied that he was the cause for the sudden spike of COVID-19 in Malaysia in early March. Furthermore, it was reported that he had exposed more than 200 individuals to the virus labelling him as an 'extraordinary spreader' (Sukumaran 2020). This information, which was intended to warn and educate the public, unfortunately, caused 'Patient 26' to be the target of criticisms by citizens all over the country.

We argue that such diagrams that link the origins of cases from one person to another are damaging even when it is anonymised. This is evident when the never-ending 
harassment had necessitated the patient to publicly defend himself (Sukumaran 2020). Similar incidents were also observed in South Korea where the public was informed of the age, gender and movement history of each individual confirmed case via a smartphone application (Kasulis 2020). While anonymised, personal information still allowed the public to probe and discover the patients' identities (Kim and Denyer 2020). We argue that sharing detailed information such as the diagram with the public does not fulfil the criteria of public interest, as it would have been sufficient to inform the public of the movement history without linking it to any patient.

Similarly, following the release of the press statement regarding the case of 'Patient 1580' on 5 April 2020, unsurprisingly the public reacted negatively towards the patient. 'Patient 1580' was found to have infected 37 individuals, including 5 of whom had succumbed to COVID-19, as a result of her concealing her recent travel to Italy and failing to adopt self-quarantining measures (Abdullah 2020b). In response to the disclosure, a nationwide 'witch-hunt' was triggered on social media after a family member of the deceased demanded that the patient publicly apologize (Larbsib 2020). The details of 'Patient 1580' such as her name and pictures were later shared on social media by individuals who had close contact with her.

It is apparent that placing the blame on anonymised patients have similar devastating effects when their identities were later revealed. We argue that such practice by the authority may be unethical as it has the potential to trigger needless overreactions from the public which can potentially cause the patients' identities to be exposed. The authorities should refrain from placing the blame on any anonymised patients as this is necessary to prevent stigma and discrimination towards them.

\section{Preventing discrimination against vulnerable groups}

Xenophobia or prejudice against people from other countries is a common occurrence in the current pandemic. In the beginning, Chinese nationals were discriminated all over the world (Al Jazeera 2020a) including in Malaysia. However, this xenophobia has recently shifted to migrant workers and illegal immigrants in Malaysia. We argue that the apparent discrimination against these groups in the country has been partly contributed by the disclosure of the ethnicity and nationality of the newly confirmed cases to the public.

Initially, Malaysia was committed to ensuring that vulnerable groups have equal access to COVID-19 testing and treatment. This is evident when the government announced on 30 January 2020 that all fees would be waived for non-nationals suspected to have the virus or have close contact with confirmed cases who sought treatment in public healthcare facilities (Ministry of Health Malaysia 2020b). However, in early May 2020, the government announced that all migrant workers across the country must be tested, and the cost would not be borne by the government, but rather by their employers (Anis and Bedi 2020). The announcement was a knee jerk reaction after numerous COVID-19 clusters were discovered among migrant workers (Hassan 2020). Furthermore, reporting the clusters as 'security guard cluster', 'construction worker cluster' or 'foreign worker cluster' by the mass media is often dehumanizing (Hakim 2020; Code Blue 2020; Yusof and Landau 2020). With the growing number of positive cases, there has been a strong pushback from the public, fearful of the virus being harboured by migrant workers and illegal immigrants (Minter 2020). 
In mid-April 2020, the Malaysian Navy turned away a boat with more than 200 Rohingya refugees on board (Human Rights Watch 2020). Later, large scales of arrests of undocumented immigrants were made in Kuala Lumpur on 1 May 2020, with more than 700 individuals were taken into custody (Al Jazeera 2020b). Malaysian authorities have cited COVID-19 containment to justify both events (Ahmed 2020). The arrests have been criticized by the United Nations in Malaysia as it may push the vulnerable groups into hiding and prevent them from seeking treatment (New Straits Times 2020). Consequently, there have been multiple reports of migrants who have attempted and succeeded in fleeing quarantine centres (Kaur 2020; Zolkepli and Camoens 2020).

Although the authorities had not revealed the patients' identities, it can be argued that the sharing of their nationalities enabled them to be stigmatized. While the collection of information such as nationality and ethnicity may be necessary for public health interventions, the disclosure of these data to the public has no beneficial impact to the public. Disclosing the location of new clusters without revealing the nationalities can be considered sufficient to educate the public to adopt preventive measures.

We suggest that the information dissemination regarding the vulnerable groups should be carefully done to prevent the public from associating them with COVID19. The mass media should avoid citing the name of the clusters according to nationality, ethnicity, religion, or occupation to minimize the negative impact against them.

\section{Responding to fake news or false information}

Infodemic not only leads to unnecessary anxiety and panic from the public but may also breed hatred and discrimination towards the affected communities. The Malaysian authorities have adopted two measures to contain the spread of misinformation in the country.

Firstly, the Malaysian Communications and Multimedia Commission (MCMC), which is the regulatory body for the communication and multimedia industry in the country, has launched a rapid response team to monitor suspicious news or allegations made on the internet or social media regarding COVID-19 (Arumugam 2020). The team receives and checks the facts of all suspicious social media posts, blogs or messages reported by the public. Any social media post or article that requires clarification will be forwarded to the relevant authorities for verification. The social media post or article in question will then be posted on the website sebenarnya.my (translation: the truth) and labelled as fake news. As of mid-May 2020, 256 fake news have been debunked and made public through the website.

Secondly, as of 8 May 2020, the police and the MCMC have investigated 262 individuals who were caught disseminating fake news and false information (Arumugam 2020). Members of the public have been repeatedly warned against disseminating fake news or false information regarding COVID-19. They have also been informed that action against errant individuals can be initiated under Section 233(1) and 242 of the Multimedia and Communications Act 1998, which upon conviction is liable to a fine up to RM100,000.00 or imprisonment up to two years or both. Unfortunately, despite these warnings, fake news regarding COVID-19 remain rampant in Malaysia, with previously debunked allegations resurfacing and being 
recirculated on social media. At the end of the day, the duty falls on the members of the public to verify the information before sharing it with others.

\section{Conclusion}

Many of us are in uncharted territory and have never experienced such a pandemic during our lifetimes. These are challenging times, and by virtue of being a part of humanity, everyone has a responsibility to work together to overcome the challenges posed by COVID-19. In this paper, it has been illustrated that responding in an ethical manner when disseminating information regarding and related to COVID-19 is a positive moral duty that belongs to everyone. For those working in the mass media, there is a need for ethical journalism; and for private individuals who use social media, it is equally important to determine beforehand whether the dissemination of a piece of information is interesting to the public or such disclosure of information is in the public's interest.

The distinction of information that is disclosed in the public interest, and those that are interesting to the public, and ethical journalism are both important because on a societal level, the public needs to remain calm and be cooperative in efforts to prevent the spread of the disease; while on a more personal level, the sharing of personal information can lead to stigmatization, discrimination and blame.

Press statements and news reports that assign blame on patients for 'spreading COVID-19' should be avoided to prevent them from being stigmatized. In responding to the sharing of false information, the Malaysian authorities have responded well by developing an online platform that allows the public to fact-check all information shared across social media. Additionally, numerous criminal investigations have been initiated by the authorities against individuals who disseminate fake news or false information. Unfortunately, the difficult part is to ensure members of the public behave ethically. There is a strong need for the authorities to increase awareness among the public on their ethical duty to be responsible for what they share on social media to curb infodemic and also to prevent them from sharing unnecessary personal details of patients and affected individuals.

In responding ethically, the health and social media literacy of all citizens need to be enhanced together by utilizing critical thinking skills to ensure that the validity of the information is checked, and the usefulness of the information is considered before the forward or send button is clicked. In this manner, we will all be playing our small part in this big effort to combat COVID-19, for together everybody achieves more.

\section{Availability of data and material Not applicable.}

Code availability Not applicable.

Funding information No funding received.

\section{Compliance with ethical standards}

Conflict of interest On behalf of all authors, the corresponding author states that there is no conflict of interest. 


\section{References}

Abdullah, Noor Hisham. 2020a. Kenyataan Akhbar KPK 4 Mac 2020 - Situasi Semasa Jangkitan Penyakit Coronavirus 2019 (COVID-19) di Malaysia [Updates on the Coronavirus Disease 2019 (Covid-19) Situation in Malaysia, 4 March 2020]. From the Desk of the Director-General of Health Malaysia, 4 March 2020. https://kpkesihatan.com/2020/03/04/kenyataan-akhbar-kpk-4-mac-2020-situasi-semasajangkitan-penyakit-coronavirus-2019-covid-19-di-malaysia.

Abdullah, Noor Hisham. 2020b. Kenyataan Akhbar KPK 5 April 2020 - Situasi Semasa Jangkitan Penyakit Coronavirus 2019 (COVID-19) di Malaysia [Updates on the coronavirus disease 2019 (Covid-19) situation in Malaysia, 5 April 2020]. From the Desk of the Director-General of Health Malaysia, 5 April 2020. https://kpkesihatan.com/2020/04/05/kenyataan-akhbar-kpk-5-april-2020-situasi-semasajangkitan-penyakit-coronavirus-2019-covid-19-di-malaysia/.

Ahmed, Kaamil. 2020. Malaysia cites Covid-19 for rounding up hundreds of migrants. The Guardian, 2 May 2020. https://www.theguardian.com/global-development/2020/may/02/malaysia-cites-covid-19-forrounding-up-hundreds-of-migrants.

Anis, Mazwin Nik, and Rashvinjeet S. Bedi. 2020. Foreign workers must be tested. The Star, 5 May 2020. https://www.thestar.com.my/news/nation/2020/05/05/foreign-workers-must-be-tested.

Arumugam, Tharanya. 2020. Fake news on Covid-19 still rampant. New Straits Times, 9 May 2020. https://www.nst.com.my/news/nation/2020/05/591198/fakenews-covid-19-still-rampant-nsttv.

Atan, Arif. 2020. Satu Malaysia Sengsara, Netizen Kecam Pesakit Covid-19 Ke-136 'Kuat Merayap'. Malaysia Dateline, 8 April 2020. https://malaysiadateline.com/satu-malaysia-sengsara-netizen-kecampesakit-covid-19-ke-136-kuat-merayap/.

BBC News. 2020. Coronavirus pandemic: Tracking the global outbreak. BBC News, 13 April 2020. https://www.bbc.com/news/world-51235105.

Berlinger, Nancy, Matthew Wynia, Tia Powell, D. Micah Hester, Aimee Milliken, Rachel Fabi, Felicia Cohn, Laura K. Guidry-Grimes, Jamie Carlin Watson, Lori Bruce, Elizabeth J. Chuang, Grace Oei, Jean Abbott, and Nancy Piper Jenks. 2020. Ethical framework for health care institutions \& guidelines for institutional ethics services responding to the coronavirus pandemic. The Hastings Center, 16 March 2020. https://www.thehastingscenter.org/ethicalframeworkcovid19/.

British Medical Association. 2020. Confidentiality and disclosure of health information tool kit. London: British Medical Association. https:/www.bma.org.uk/media/1846/bma-confidentiality-and-healthrecords-toolkit.pdf. Accessed 6 June 2020.

Code Blue. 2020. Migrant worker covid-19 cluster hits Malaysia. Code Blue, 8 May 2020. https://codeblue. galencentre.org/2020/05/08/migrant-worker-covid-19-cluster-hits-malaysia/.

Department of Health (Ireland). 2020. Ethical framework for decision-making in a pandemic. https://assets. gov.ie/72072/989943ddd0774e7aa1c01cc9d428b159.pdf. Accessed 6 June 2020.

Al Jazeera. 2020a. Elderly man attacked in Canada, targeted with coronavirus slur. Al Jazeera, 23 April 2020. https://www.aljazeera.com/news/2020/04/elderly-man-attacked-canada-targeted-coronavirus-slur$200423044938550 . \mathrm{html}$.

Al Jazeera. 2020b. Malaysia 'detains migrants, refugees' amid coronavirus lockdown. Al Jazeera, 1 May 2020. https:/www.aljazeera.com/news/2020/05/malaysia-detains-migrants-refugees-coronaviruslockdown-200501134602431.html.

de la Garza, Alejandro. 2020. How social media is shaping our fears of - and response to - the Coronavirus. Time, 16 March 2020. https:/time.com/5802802/social-media-coronavirus/.

Greenberg, A., and J. Rosner. 2020. Voters are turning against Trump because of his leadership in the pandemic. Washington Post, 24 April 2020. https://www.washingtonpost.com/outlook/2020/04/23 /trump-leadership-coronavirus-election-biden/.

Hakim, Akmal. 2020. New construction cluster identified in Setia Alam. The Rakyat Post, 9 May 2020. https://www.therakyatpost.com/2020/05/09/newconstruction-cluster-identified-in-setia-alam/.

Hamid, Amir Abd, and Raja Noraina Raja Rahim. 2020. KKM Nafi Dedah Maklumat Peribadi Pesakit. Harian Metro, 7 April 2020. https://www.hmetro.com.my/mutakhir/2020/04/563704/kkm-nafi-dedahmaklumat-peribadi-pesakit.

Hao, Karen, and Tanya Basu. 2020. The coronavirus is the first true social-media "Infodemic". MIT Technology Review. https://www.technologyreview.com/s/615184/the-coronavirus-is-the-first-truesocial-media-infodemic/. Accessed 12 February 2020.

Hassan, Hazlin. 2020. Coronavirus: Malaysia frets over health of migrant Workers in Battle against virus. Straits Times, 20 April 2020. https://www.straitstimes.com/asia/se-asia/coronavirus-malaysia-frets-overhealth-of-migrant-workers-in-battle-against-virus. 
Human Rights Watch. 2020. Malaysia: Allow Rohingya refugees ashore, Covid-19 no basis for pushing back boats. Human Rights Watch, 18 April 2020. https://www.hrw.org/news/2020/04/18/malaysia-allowrohingya-refugees-ashore.

Kanekar, Amar Shireesh, and Avinash Thombre. 2019. Fake medical news: Avoiding pitfalls and perils. Family Medicine and Community Health 7 (4): e000142. https://doi.org/10.1136/fmch-2019-000142.

Kaur, Minderjeet. 2020. 145 construction workers on the run after Covid-19 swab test. FMT News, 6 May 2020. https:/www.freemalaysiatoday.com/category/nation/2020/05/06/145-construction-workers-on-therun-after-covid-19-swab-test/.

Kasulis, Kelly. 2020. S Korea's smartphone apps tracking coronavirus Won't stop buzzing. Al Jazeera, 9 April 2020. https://www.aljazeera.com/news/2020/04/korea-smartphone-apps-tracking-coronavirus-won-stopbuzzing-200408074008185.html.

Keong, Gan Chee, Ahmad Azam Mohd, Shariff, Ramalinggam, Rajamanickam, and Nazura Abdul, Manap. 2016. An overview on the public interest litigation in Malaysia: Development and dilemma under provision of remedies for enforcement of fundamental rights. Mediterranean Journal of Social Science 7 (2): 114-118. https://doi.org/10.5901/mjss.2016.v7n2p114.

Kim, M.J., and S. Denyer. 2020. A 'Travel Log' of the times in South Korea: Mapping the movements of coronavirus carries. Washington Post, 13 March 2020. https://www.washingtonpost.com/world/asia pacific/coronavirus-south-korea-tracking-apps/2020/03/13/2bed568e-5fac-11ea-ac50-18701e14e06d_story.html.

Knight, Victoria. 2020. Covid-19: Beware online tests and cures, experts say. The Guardian, 9 April 2020. https://www.theguardian.com/world/2020/mar/31/coronavirus-covid-19-fake-tests-cures.

Lai, Nancy. 2020. Enough goods, panic buying caused by fake news. Borneo Post, 23 March 2020. https://www.theborneopost.com/2020/03/23/enough-goodspanic-buying-caused-by-fake-news/.

Larbsib, Amat. 2020. Kes Kluster Itali Di Sarawak, Kematian 5 Sekeluarga Akhirnya Dirungkai Berpunca Dari 'Officemate'. OHBULAN!, 6 April 2020. https://ohbulan.com/kes-kluster-itali-di-sarawak-kematian5-sekeluarga-akhirnya-dirungkai-berpunca-dari-officemate.

Wah, Milton Lum Siew, Suraiya H. Hussain, Sirajoon Noor S.M. Abdul Ghani, Abdul Gani Mohammed Din, and Tee Lian Kim. 2011. Confidentiality guideline. Malaysian Medical Council, 11 October 2011. https://mmc.gov.my/wp-content/uploads/2019/11/Confidentiality-guidelines.pdf.

Martin, Penny. 2003. Defining and refining the concept of practising in 'the public Interest'. Alternative Law Journal 28 (1): 3. https://doi.org/10.1177/1037969X0302800101.

Ministry of Health Malaysia. 2020a. Mental health and psychosocial support in Covid-19. In Guidelines Covid-19 Management No.5/2020. https://www.moh.gov.my/moh/resources/Penerbitan/Garis\%20 Panduan/COVID19/Annex_33_Mental_health_and_Psychosocial_support_23032020.pdf. Accessed 15 May 2020.

Ministry of Health Malaysia. 2020b. Pengecualian Caj Perubatan Kepada Pesakit Warga Asing Yang Dijangkititi 2019-Ncov. https://www.moh.gov.my/index.php/database_stores/attach_download/312/375. Accessed 15 May 2020.

Molina, Maria D., S. Shyam Sundar, Thai Le, and Dongwon Lee. 2019. "Fake News" is not simply false information: A concept explication and taxonomy of online content. American Behavioral Scientist. https://doi.org/10.1177/0002764219878224.

Minter, Adam. 2020. Is Covid-19 bringing out the worst in Malaysians? New Straits Times, 16 May 2020. https://www.nst.com.my/opinion/columnists/2020/05/593153/covid-19-bringing-out-worst-malaysians.

New Straits Times. 2020. UN: Use alternatives to detention in fight against Covid-19. New Straits Times, 2 May 2020. https://www.nst.com.my/news/nation/2020/05/589262/un-use-alternatives-detention-fightagainst-covid-19.

Ortutay, Barbara, and David Klepper. 2020. Covid-19 outbreak means (Mis)Information overload: How to cope. The Star, 23 March 2020. https:/www.thestar.com.my/tech/tech-news/2020/03/23/covid-19outbreak-means-misinformation-overload-how-to-cope.

Sukumaran, Tashny. 2020. I'm not patient zero': Malaysia's $26^{\text {th }}$ coronavirus patient speaks up about new Covid-19 cluster. South China Morning Post, 6 March 2020. https:/www.scmp.com/week-asia/healthenvironment/article/3073991/im-not-patient-zero-malaysias-26th-coronavirus-patient.

The Star. 2020a. Dr Noor Hisham a top professional in covid-19 fight. The Star, 16 April 2020. https://www. thestar.com.my/news/nation/2020/04/16/dr-noorhisham-a-top-professional-in-covid-19-fight.

The Star. 2020b. Surviving Covid-19: M'sian man shares his coronavirus experience. The Star, 12 March 2020. https://www.thestartv.com/v/surviving-covid-19-m-sian-man-shares-his-coronavirus-experience.

United Nations. 1948. The Universal Declaration of Human Rights. https://www.un.org/en/universaldeclaration-human-rights/. 
Wang, Yuxi, Martin McKee, Aleksandra Torbica, and David Stuckler. 2019. Systematic literature review on the spread of health-related misinformation on social media. Social Science \& Medicine 240: 112552. https://doi.org/10.1016/j.socscimed.2019.112552.

West, Darrell M. 2017. How to combat fake news and disinformation. Brookings, 18 December 2017. https://www.brookings.edu/research/how-to-combatfake-news-and-disinformation/.

World Health Organisation. 2020a. Coronavirus disease (Covid-19) pandemic. https://www.who. int/emergencies/diseases/novelcoronavirus-2019. Accessed 6 June 2020.

World Health Organisation. 2020b. Novel coronavirus (2019-Ncov) situation report-13. https://www.who. int/docs/defaultsource/coronaviruse/situation-reports/20200202-sitrep-13-ncov-v3.pdf. Accessed 6 June 2020.

Yusof, Teh Athira, and Esther Landau. 2020. Covid-19: New security guards cluster in Cheras. New Straits Times, 7 May 2020. https:/www.nst.com.my/news/nation/2020/05/590672/covid-19-new-securityguards-cluster-cheras.

Zarocostas, John. 2020. How to fight an Infodemic. Lancet 395 (10225): 676. https://doi.org/10.1016/S01406736(20)30461-X.

Zolkepli, Farik, and Austin Camoens. 2020. Cops looking for nine foreigners who escaped Covid-19 quarantine Centre. The Star, 6 May 2020. https://www.thestar.com.my/news/nation/2020/05/06/copslooking-for-nine-foreigners-who-escaped-covid-19-quarantine-centre.

Publisher's Note Springer Nature remains neutral with regard to jurisdictional claims in published maps and institutional affiliations. 